\title{
O direito ao aborto no debate legislativo brasileiro: a ofensiva conservadora na Câmara dos Deputados
}

\author{
Luis Felipe Miguel \\ Flávia Biroli \\ Rayani Mariano
}

\section{Introdução}

Questão polêmica, que provoca reações extremas e apaixonadas, o direito ao aborto tem ganhado destaque crescente no debate público brasileiro ${ }^{1}$. Por um lado, atores políticos conservadores, em geral vinculados a organizações religiosas, fizeram do combate ao "assassinato de bebês" um dos temas centrais de seus discursos. Por outro, o movimento feminista priorizou a luta pela descriminalização do aborto, entendida como uma das condições para que as mulheres tenham plena autonomia sobre seus próprios corpos. Em mobilizações de rua, nas discussões nas novas mídias digitais e, em menor medida, na imprensa, o direito ao aborto tornou-se, da redemocratização para cá, um item importante da agenda.

Tornou-se também uma questão de relativo destaque na política institucional. Foi um ponto importante nas campanhas eleitorais presidenciais de 2010 e 2014 e entrou na pauta de muitas candidatas e candidatos ao Poder Legislativo em todo o país. Recebeu também atenção no Congresso Nacional, na forma de pronunciamentos em plenário, de audiências públicas nas comissões e de projetos de lei. Mas, sobretudo a partir dos anos 2000, essa movimentação ocorreu na forma de uma reação, na qual sobressaem as estratégias de grupos religiosos - especialmente católicos e evangélicos, mas também espíritas. Com isso, o debate nas eleições e nas arenas legislativas, no Brasil, tem sido muito mais unilateral do que em outros espaços sociais. Tal configuração é efeito da maior prioridade dos grupos religiosos para essa temática, o que se liga às estratégias para as relações entre líderes e fiéis, mas também à identificação, por parte desses grupos, da presença de posições mais progressistas, no âmbito do Poder Executivo, resultantes de uma maior permeabilidade à agenda dos movimentos feministas situação que mudou após o golpe de 2016, que destituiu a presidente Dilma Rousseff.

\footnotetext{
${ }^{1}$ A discussão aqui apresentada faz parte das pesquisas: "Direito ao aborto e sentidos da maternidade: atores e posições em disputa no Brasil contemporâneo", financiada pelo edital MCTI/CNPq/SPM-PR/MDA 32/2012, e "Representação substantiva e gênero no Brasil", financiada pelo edital MCTI/CNPq/MEC/Capes 18/2012. Agradecemos às bolsistas do Grupo de Pesquisa sobre Democracia e Desigualdades (<www.demode.unb.br >) que trabalharam na coleta dos dados da pesquisa: Amanda Seabra, Carolina Souto, Débora Françolin, Juliana Góes, Luciana Keller, Isabella Rodrigues, Karine Farinha, Laura Sousa e Raquel Labarrere. A coleta ocorreu sob a supervisão de Rayani Mariano e Gabriela Dornelles.
} 
A luta contra o aborto foi a plataforma de inúmeros candidatos às eleições legislativas recentes, tanto para a Câmara dos Deputados quanto para as assembleias legislativas estaduais. No Horário de Propaganda Eleitoral Gratuita em agosto e setembro de 2014, a "defesa da vida" foi um dos bordões mais recorrentes, ao lado de sua parceira permanente, a "defesa da família". Se muitos candidatos às eleições proporcionais identificavam nas bandeiras da direita religiosa a melhor maneira de sensibilizar o eleitorado, nas eleições majoritárias os candidatos se viram constrangidos a afirmar publicamente sua oposição ao direito de escolha das mulheres. Se não o fizessem, seriam vetados pelos líderes religiosos e sofreriam campanha negativa nas igrejas.

A utilização da temática do aborto como forma de chantagem contra as posições políticas mais progressistas, nas eleições de 2014, foi uma reedição da estratégia de sucesso utilizada na disputa presidencial anterior. Em 2010, a ofensiva religiosa relativa à "defesa da vida" - e também a outros temas da chamada "agenda moral", como a oposição aos direitos dos homossexuais - foi importante para levar a eleição para o segundo turno, em prejuízo da então candidata Dilma Rousseff, e para dela colher compromissos conservadores².

Discursos no Congresso Nacional e proposições legislativas acompanham a mesma dinâmica. Basta observar que uma frente suprapartidária contra o aborto reuniu, em 2014, 167 deputados (quase um terço da Casa, que conta com 513 representantes) e 13 senadores (dos 81 que compõem o Senado Federal). Não existe frente similar em prol da descriminalização da interrupção voluntária da gravidez. Em suma, pode-se dizer que o debate na política institucional brasileira, seja nas campanhas eleitorais, seja no parlamento, tem tomado a forma de uma ofensiva conservadora, que tem em muitos casos - e cada vez mais - se tornado uma atuação retrógrada, isto é, que pretende desfazer os avanços pontuais na legislação e nas políticas públicas.

Este artigo discute como se deu o debate sobre aborto na Câmara dos Deputados brasileira, analisando a totalidade dos discursos sobre a questão pronunciados em plenário, no período de 24 anos que vai da 49a à 54a legislaturas (de fevereiro de 1991 até janeiro de 2015). Ele se ancora, portanto, em um estudo exploratório, com acompanhamento de longo prazo, que buscou identificar os principais atores políticos envolvidos e as linhas gerais em que se desenvolveu a discussão parlamentar sobre o tema, nas legislaturas eleitas sob a vigência da Constituição democrática de 1988.

A seção "O direito ao aborto no Brasil" sumariza a evolução da discussão sobre essa questão nas últimas décadas. A seção "O aborto na Câmara dos Deputados" apresenta os dados da pesquisa, relativos às posições nos discursos proferidos na Câmara e o perfil dos protagonistas do debate. A seção "Os argumentos nos discursos" trata dos argumentos utilizados. A breve "Conclusão", enfim, interpreta os achados e indica estratégias para romper o impasse que hoje se apresenta na abordagem sobre o aborto e direitos reprodutivos, nas arenas da política institucional brasileira.

\footnotetext{
${ }^{2}$ A esse respeito, conferir Machado (2012), Mantovani (2014), Miguel (2012) e Mota e Biroli (2014).
} 


\section{O direito ao aborto no Brasil}

Os dados resultantes da pesquisa permitem compreender como se definiram os padrões no debate sobre aborto na Câmara dos Deputados nas últimas décadas. A análise dos deslocamentos nesses padrões demonstra a configuração de uma ofensiva conservadora contra o direito ao aborto, que se acentua e assume novos padrões a partir dos anos 2000. Essa ofensiva corresponde tanto a uma atuação crescente dos grupos religiosos contrários ao aborto no Poder Legislativo, que vêm dando maior prioridade ao tema nas suas campanhas e na sua atuação dentro do Congresso, quanto ao recuo das posições mais abertamente favoráveis à legalização. Os deslocamentos não estão, assim, contidos apenas nas posições contrárias ao direito ao aborto. Estão presentes também entre as favoráveis, que mobilizam cada vez menos a autonomia das mulheres como valor. O argumento de que o acesso ao aborto é uma questão de saúde pública, sem dúvida relevante, ofusca o entendimento, cada vez mais constrangido nesse debate, de que o aborto é um direito de cidadania das mulheres. Ou seja: todo o quadro do debate no Congresso brasileiro se deslocou para um patamar mais conservador.

Nesse ambiente político, defensoras dos direitos das mulheres, dentro e fora do Congresso Nacional, têm se dedicado principalmente a impedir retrocessos numa legislação que já é bastante restritiva. Desde 1940, o Código Penal brasileiro tipifica o aborto como crime, punível com prisão, com o abortamento legal sendo previsto apenas em caso de gravidez resultante de estupro ou de risco de vida para a mulher. Uma terceira exceção foi acrescentada há pouco tempo, em 2012, por decisão do Supremo Tribunal Federal (STF) tomada a partir da Ação de Descumprimento de Preceito Fundamental (ADPF) no 54, formalizada em 2004 pela Confederação Nacional dos Trabalhadores na Saúde. Ela permite a interrupção da gestação em casos de anencefalia fetal $^{3}$. É um fato que marca o descompasso nos ambientes dos três poderes, não apenas no caso do aborto, mas, de forma mais ampla, na agenda dos direitos no âmbito da sexualidade e da conjugalidade ${ }^{4}$.

A epidemia de zika, que amplia a possibilidade de má-formação fetal, levou a uma Ação Direta de Inconstitucionalidade (ADIn), junto ao STF, para produzir mais uma exceção ao impedimento à interrupção voluntária da gravidez, medida que contava com o apoio da Organização das Nações Unidas (Senra, 2016). Apresentada pela Associação Nacional dos Defensores Públicos no começo de 2016, a ADIn teve sua votação adiada várias vezes e, em março de 2017, permanecia sem definição. Mas houve outro avanço

\footnotetext{
${ }^{3}$ Para uma análise bem documentada da discussão sobre aborto no caso de anencefalia fetal e sobre pesquisas com células-tronco embrionárias no Brasil, cf. Luna (2013).

${ }^{4} \mathrm{O}$ direito ao casamento entre pessoas do mesmo sexo foi garantido pelo STF em 2011, determinando avanços que não foram possíveis no Legislativo, embora estejam presentes em iniciativas como o Projeto de Lei no 2285/2007. São casos como esses que reforçam a interpretação de que, no Brasil, o Judiciário tem definido progressos nos direitos dos homossexuais enquanto o Legislativo tem uma posição conservadora, devido sobretudo à ação organizada dos grupos religiosos (Mello, 2006, p. 498).
} 
significativo, também no âmbito do Poder Judiciário: a decisão da primeira turma do STF, em 29 de novembro de 2016, pela não punibilidade do aborto nos três primeiros meses de gestação. Tomada diante de um único caso concreto, a decisão - que aponta inconstitucionalidade nos artigos do Código Penal que criminalizam a prática - abre a possibilidade de que o Supremo estenda essa interpretação e chegue à efetiva descriminalização do aborto. Em sua esteira, no dia 6 de março de 2017, o Partido Socialismo e Liberdade (PSOL) entrou com uma ADPF para a legalização plena do aborto no Brasil ${ }^{5}$.

Há um enorme descompasso, também, entre a legislação sobre aborto e o aborto como prática efetiva das mulheres. A distância entre as normas restritivas e a realidade social das mulheres permite equiparar a proibição do aborto hoje à restrição ao divórcio no Brasil antes de 1977 (a partir de observações desses dois contextos feitas por Htun, 2003). Estima-se que mais de uma em cada cinco mulheres brasileiras fez pelo menos um aborto (Diniz e Medeiros, 2010, p. 964). No cotidiano, a crença e a adesão a religiões que condenam a interrupção voluntária da gestação não impedem que as mulheres realizem abortos, embora constranja sua expressão pública sobre o tema e sobre suas experiências (Ávila, 2006, p. 18). Mas não se trata de uma futilidade da norma, de uma diferença entre a letra da lei e a vivência concreta. A criminalização prejudica as mulheres, comprometendo sua cidadania e sua integridade física. A prática do aborto não é reduzida pela criminalização, mas brutalizada, e tanto mais perigosa para as mulheres quanto maiores são os esforços para se fazer cumprir a lei (Boltanski, 2004, p. 124).

A clandestinidade corresponde, muitas vezes, à realização do aborto em condições precárias. O grau de precariedade se vincula a variáveis ligadas entre si: condição socioeconômica das mulheres, acesso à informação e, novamente, efetividade das políticas de repressão. Mulheres mais pobres e mais jovens tendem a interromper a gravidez em piores condições, muitas vezes sem assistência de profissionais de saúde. Quando a perseguição policial e judiciária ao aborto é mais intensa, o risco para esses profissionais também é maior, reduzindo a oferta de serviços clandestinos, ampliando seu custo, piorando as condições em que são prestados e aumentando a assimetria de poder entre o médico ou enfermeiro e a gestante que recorre a ele. $O$ recente caso da jovem que, após um abortamento autoinduzido que levou a hemorragia, foi denunciada à polícia pelo médico que deveria socorrê-la (Oliveira, 2015) ilustra a vulnerabilidade que a proibição da interrupção voluntária da gravidez impõe às mulheres.

Tudo isso resulta em um número elevado de complicações e de mortes. Segundo dados oficiais do Ministério da Saúde de 2006, o aborto clandestino é a causa de 11,4\% das mortes maternas e $17 \%$ do total de mortes por razões obstétricas. Esse número é menor do que o que foi apontado por estatísticas dos anos 1990, provavelmente pela

\footnotetext{
${ }^{5}$ As três ações foram encaminhadas por duas associações profissionais e um partido porque são essas organizações que têm a prerrogativa de interpelar diretamente o STF. Em todos os casos, foram fruto de articulações do movimento feminista, com papel de destaque desempenhado pelo Anis - Instituto de Bioética, Direitos Humanos e Gênero.
} 
O DIREITO AO ABORTO NO DEBATE LEGISLATIVO BRASILEIRO: A OFENSIVA CONSERVADORA NA CÂMARA DOS DEPUTADOS

difusão do abortamento químico, proporcionado pelo uso de substâncias como o misoprostol (conhecido pelo nome da marca comercial Cytotec), em vez de métodos perfurativos ou cáusticos (Ministério da Saúde, 2009). Mas mesmo o recurso ao misoprostol inclui riscos, caso não haja supervisão especializada ou segurança quanto à origem do produto. Relatos, sobretudo de mulheres mais pobres, indicam que o acesso a substâncias abortivas na clandestinidade continua a se dar de uma forma que compromete sua saúde e também a das crianças, nos casos em que a tentativa de aborto não tem sucesso (Motta, 2012).

Diante dessa realidade, mas também dos constrangimentos cada vez maiores para a ampliação do direito das mulheres brasileiras a interromper uma gravidez indesejada, o Judiciário garantiu o acesso legal ao aborto no caso dos fetos anencefálicos, como mencionado, neste que foi o principal avanço ocorrido no Brasil em décadas, por meio de uma manobra semântica, em que, em vez de aborto, falou-se em "antecipação do parto". Já o Poder Executivo estava tomando, nos últimos anos, iniciativas no sentido de garantir o acesso das mulheres ao aborto nos casos previstos em lei. Porém, tal como ocorria com outras questões vinculadas à chamada "agenda moral" (luta contra a homofobia, campanhas de prevenção da transmissão do HIV etc.), a reação dos grupos religiosos pressionava, em grande parte dos casos com sucesso, pelo recuo e revogação das medidas. Com isso, governos e candidaturas, sobretudo a cargos executivos, têm se mostrado vulneráveis à chantagem eleitoral e à ofensiva que as igrejas têm promovido (Miguel, 2012). A situação se agravou após a derrubada de Dilma Rousseff. O novo governo apresenta um perfil homogeneamente contrário à agenda feminista e os grupos religiosos conservadores são centrais em sua base de apoio. O órgão destinado à defesa das mulheres foi rebaixado na hierarquia do Poder Executivo e tem a sua frente uma mulher identificada com a agenda cristã reacionária, com posição contrária ao direito ao aborto.

No Legislativo, os projetos que ampliam os casos de aborto legal ou descriminalizam de vez a prática têm sido arquivados ou barrados em comissões legislativas. Em fevereiro de 2015, no início da nova legislatura, havia cinco Projetos de Lei sobre o aborto tramitando na Câmara dos Deputados. Apenas um deles, O PL 20/1991, do deputado Eduardo Jorge (PT-SP), é favorável à ampliação do direito ao aborto. Desde 1997 sua tramitação está empacada, esperando uma decisão da Mesa Diretora. Entre os projetos contrários ao direito ao aborto estão o PL 4703/1998, que define o aborto como crime hediondo, e o PL 478/2007, que ganhou o nome de "Estatuto do Nascituro" e que propõe que o "nascituro", definido como "ser humano concebido, mas ainda não nascido" (artigo $2^{\circ}$ ), tenha proteção jurídica, uma vez que "sua natureza humana é reconhecida desde a concepção". O projeto determina (em seu artigo 30, parágrafo único) que "o nascituro goza da expectativa do direito à vida, à integridade física, à honra, à imagem e de todos os demais direitos da personalidade" e inclui não apenas a penalização da mulher que aborta e de quem realiza ou a auxilia na realização do aborto, mas também de quem faz "apologia do aborto ou de quem o praticou, ou 
incitar publicamente a sua prática". Em março de 2015, foi apresentado o PL 882/2015, do deputado Jean Wyllys (PSOL-RJ), descriminalizando o aborto, hoje apensado a outro projeto, que trata de oferecimento de métodos contraceptivos na rede pública de saúde e reduz as penas para esterilizações realizadas sem consentimento dos pacientes.

Embora a atuação de parlamentares religiosos no Congresso seja notável na temática do aborto em todo o período pesquisado, sua atuação se tornaria mais articulada com a formação de frentes parlamentares focadas no tema. Elas têm sido estratégicas para fazer avançar temáticas de destaque na agenda dos parlamentares evangélicos (Machado, 2013), como a do aborto, articulada sistematicamente à da "defesa da família". Evidentemente, não é possível tomar as diferentes denominações religiosas que têm presença no debate público no Brasil hoje como se fossem um bloco na sua atuação relativa às políticas reprodutivas e em suas concepções das relações de gênero. Há posições divergentes; por exemplo, o chefe de uma das maiores igrejas neopentecostais do país, o bispo Edir Macedo, da Igreja Universal do Reino de Deus, defende publicamente, há tempos, a legalização do aborto.

Em 2003, foi criada a Frente Parlamentar Evangélica, resultante da articulação liderada pelo deputado Adelor Vieira (PMDB-SC), vinculado à Assembleia de Deus ${ }^{6}$. Ela tem sido, desde então, base importante para a articulação contrária ao direito ao aborto na Câmara dos Deputados. As frentes focadas no aborto, formadas para impedir avanços na legislação relativa a esse tema, têm, no entanto, reunido parlamentares de diferentes denominações religiosas.

A Frente Parlamentar em Defesa da Vida - Contra o Aborto foi registrada pela primeira vez em 2005, tendo à frente o deputado espírita Luiz Bassuma, da Bahia7, que foi também o parlamentar que mais se pronunciou sobre a temática no período analisado pela pesquisa. Nas legislaturas subsequentes, ela seria registrada novamente, acompanhada por novas frentes focadas no "direito à vida", presididas por parlamentares espíritas, católicos e evangélicos das igrejas Assembleia de Deus e Sara nossa Terra, filiados ao PDT, PPS, PV, PMDB e PFL/DEM ${ }^{8}$. Esse é um dos elementos que, em conjunto com a atuação na proposição de projetos, nas comissões e por meio de discursos em plenário, permitem observar que a liderança nessa temática não se restringe aos parlamentares evangélicos e não está situada em um ou outro espectro ideológico no que se refere aos partidos políticos. Isso não significa anular a importância dos deputados

\footnotetext{
${ }^{6}$ Quando foi criada, em 2003, a Frente contava com 58 parlamentares, entre os quais 23 (39,6\%) pertenciam à Assembleia de Deus. Os demais eram vinculados principalmente a igrejas Batista, Universal, Presbiteriana e Quadrangular (<http://www.fpebrasil.com.br/portal/index.php/a-frente/sobre-a-fep>. Acesso em: 21 fev. 2015). De lá para cá, a bancada evangélica cresceu mais de três vezes, chegando em 2015 a 196 deputados de 23 partidos diferentes (<http://apublica.org/2016/02/truco-as-bancadas-dacamara/>. Acesso em: 21 fev. 2015).

${ }^{7}$ Eleito pelo PT, o deputado Luiz Bassuma foi suspenso do partido em setembro de 2009, por desrespeitar resolução partidária de 2007 favorável à descriminalização do aborto. O deputado, então, filiou-se ao PV.

${ }^{8} \mathrm{Na} 55^{a}$ Legislatura, que está fora do escopo da pesquisa, as frentes focadas na "defesa da vida" seriam presididas por deputados filiados ao PRB e ao PROS e vinculados às igrejas Batista e Assembleia de Deus.
} 
evangélicos, que imprimiram uma nova dinâmica a essas disputas. É entre eles, ainda que existam diferenças importantes entre as igrejas e suas lideranças (Machado e Burity, 2014), que aborto e "defesa da família" se tornaram estratégias para a construção de carreiras políticas e de sua imagem pública como deputados.

Em conjunto, as propostas patrocinadas por esse conjunto de parlamentares e frentes com base religiosa, que passaremos a chamar de bancada religiosa, pretendem: (1) revogar todas as exceções à proibição à interrupção da gravidez; (2) ampliar as penalidades em caso de aborto ilegal; (3) criar um cadastro nacional de grávidas, de maneira a facilitar a perseguição daquelas que optam pelo aborto; (4) estimular que a gravidez resultante de estupro não seja interrompida, com incentivo financeiro para a vítima que decidir ter o filho (a chamada "bolsa estupro"); e/ou (5) estabelecer que o direito à vida seja protegido "desde a concepção", formulação que buscam inserir na própria Constituição brasileira.

Em sua análise do debate sobre aborto no Congresso Nacional, Rocha, Rostagnol e Gutierrez (2009, p. 221) identificaram três etapas. Na primeira, entre as décadas de 1940 e 1970, o debate foi incipiente e restrito, sobretudo quando se considera a participação dos atores políticos. A segunda etapa correspondeu à intensificação do debate nos anos 1980, período de transição da ditadura instaurada em 1964 para a democracia, devido à maior atuação dos movimentos sociais no debate público, entre eles os movimentos de mulheres. A partir da década de 1990, teríamos a consolidação desse debate, com a ampliação não apenas da representação feminina no Congresso considerando sobretudo a chegada de mulheres cujas trajetórias estão relacionadas aos movimentos de mulheres e feministas -, mas também o aumento do número de congressistas vinculados a denominações religiosas.

A pesquisa que apresentamos aqui colabora para identificar esses padrões e amplia a análise de como se definiram a partir da década de 1990. As diferenças entre o debate que se deu ao longo dos anos 1990 e o debate a partir dos anos 2000, que serão expostas mais adiante, corroboram a hipótese já anunciada, de que houve nesse período um fechamento do debate, que assume cada vez mais a forma de uma ofensiva conservadora e mesmo retrógrada.

Já nos anos 1990, as tentativas feitas pelos movimentos feministas de ampliação do debate e de avanços na legislação relativa ao aborto esbarraram na ação das igrejas, tendo ainda à frente a Igreja Católica. Na Assembleia Nacional Constituinte, os movimentos feministas e seus aliados tiveram sucesso ao barrar a tentativa da Igreja Católica de incluir, no artigo $5^{\circ}$ da Constituição Federal de 1988, o princípio do "direito à vida desde a concepção". No entanto, isso não significou que os movimentos feministas favoráveis ao direito ao aborto tenham sido vencedores. A "Carta das mulheres", enviada aos parlamentares constituintes com uma pauta de reivindicações feitas pelos movimentos feministas em conjunto com o Conselho Nacional das Mulheres, demandava garantias para que as mulheres decidissem sobre seu corpo, mas não mencionava o aborto, no que foi considerado "um recuo tático diante do pensamento conservador" 
(Pinto, 2003, p. 76).

No início dos anos 1990, a discussão esteve em grande medida vinculada a projetos de lei que propunham garantir o acesso das mulheres ao aborto legal na rede pública de saúde ou então à descriminalização completa da prática (PLs 20/1991 e 1135/1991). Projetos de lei apresentados nos anos seguintes, buscando garantir o acesso ao aborto legal na rede de saúde (PL 20/1991) ou então descriminalizando plenamente a prática (PL 1135/1991), tiveram longa tramitação e pautaram a discussão no Congresso. Grupos religiosos se mobilizaram, com êxito, para impedir sua aprovação. Foi quando passaram a atuar mais sistematicamente, ao lado da Igreja Católica, as igrejas neopentecostais, cujos representantes no parlamento se tornaram importantes participantes do debate.

Em 1995, a proposta de garantir a "vida desde a concepção", derrotada na Constituinte, voltou por meio de Proposta de Emenda Constitucional apresentada por um dos deputados mais ativos na oposição ao direito ao aborto no período, Severino Cavalcanti (PFL-PE). No ano seguinte, a PEC 25/1995 foi derrotada na Comissão Especial determinada para sua discussão e em plenário (Rocha, 2008). A derrota após rápida tramitação revela, ainda na metade dos anos 1990, a relativa fragilidade, no Congresso, das posições mais radicais de oposição ao direito ao aborto. A partir daí, porém, a situação se transforma, com a campanha de grupos religiosos contra a interrupção voluntária da gravidez ganhando crescente ressonância nos espaços da política institucional.

A maior presença e organização dos parlamentares evangélicos é, sem dúvida, um fato relevante, sem o qual não seria possível explicar a ofensiva ampliada contra o direito ao aborto nos anos 2000. Mas a liderança do movimento contra o direito ao aborto ainda é exercida pela Igreja Católica, que permanece na posição de maior denominação religiosa do país. Tanto por iniciativa de prelados individuais quanto de suas instâncias hierárquicas, ela intensificou a verbalização de sua oposição à interrupção voluntária da gravidez dos anos 1990 em diante. A articulação teve seus picos com a Campanha da Fraternidade de $2008^{9}$, que elegeu o "direito à vida" como temática, e com as visitas papais, sobretudo a terceira visita do papa Wojtyla (João Paulo II), em 1997, e a visita do papa Ratzinger (Bento XVI), em 2007, em que a oposição ao aborto foi destaque ${ }^{10}$.

Nesse processo, o custo para a atuação de parlamentares e integrantes do governo a favor do direito ao aborto foi se tornando cada vez maior. As ações do ministro

\footnotetext{
9 As "campanhas da fraternidade" são ofensivas anuais de proselitismo católico, coordenadas pela Confederação Nacional dos Bispos do Brasil, que ocorrem desde os anos 1960. A cada ano, um tema é destacado como eixo da campanha.

${ }^{10}$ Na visita do papa Bergoglio (Francisco), em 2013, o tema ganhou menos atenção, o que talvez indique que a Cúria percebe o esgotamento desse filão. A "modernização" que o novo papa vem buscando para a Igreja inclui a maior tolerância para com os homossexuais, mas não uma abertura para o direito ao aborto, que ele condenou veementemente em mais de uma ocasião (Lopes, 2014; Veja.com, 2014), ainda que com menos frequência que seus antecessores.
} 
da Saúde durante o segundo governo Lula, José Gomes Temporão, que em 2007 chegou a propor a realização de um plebiscito para que a população pudesse optar pela legalização do aborto, recuando depois da oposição pública dos porta-vozes de igrejas que têm se colocado frontalmente contra esse direito e da Frente Parlamentar Mista em Defesa da Vida - Contra o Aborto, são um exemplo da dinâmica que se estabeleceria. Ela culminaria no recurso ao aborto como estratégia para fazer recuar candidatos e candidatas, especialmente a então candidata à presidência Dilma Rousseff (PT) nas eleições de 2010. O controle do enquadramento do debate público sobre o tema, por parte das igrejas, foi garantido por estratégias casadas de candidatos de oposição ao PT, pelo recuo do próprio PT (Miguel, 2012) e pela atuação dos meios de comunicação, em convergência com os candidatos de oposição (Mantovani, 2014) ${ }^{11}$. Em maio de 2014, a Portaria 415, do Ministério da Saúde, que aumentava a remuneração para as cirurgias no sistema público de saúde nos casos de aborto previsto por lei, também foi revogada, poucos dias depois de assinada, na esteira de manifestações de parlamentares religiosos.

É levando em conta a forma assumida por essas disputas, e a ampliação da atuação política das igrejas nessa agenda, que surgiram interpretações de que o acirramento dos antagonismos produziu uma paralisia na agenda do aborto no Brasil (Rocha, 2006). A reação conservadora se ampliou, por meio do avanço da atuação de grupos religiosos, estrategicamente calcado em uma agenda moral conservadora, enquanto a ação favorável aos direitos das mulheres não ganhou a mesma prioridade, sobretudo no Congresso, mas também no Executivo. A atuação contrária ao aborto apoia-se no discurso conservador "a favor da família", enquanto procura inibir as iniciativas de reconhecimento da pluralidade de arranjos familiares e, sobretudo, dos direitos dos indivíduos, forçando também um retrocesso conservador, que procura recuperar os direitos da família como entidade (Biroli, 2014; Machado, 2013), em contraposição à afirmação dos direitos individuais ${ }^{12}$. As ações públicas em nome dessa agenda têm sido um modo privilegiado de construção da identidade política de parlamentares cristãos, em busca de votos entre os "fiéis", e de pressões sobre o governo.

Por isso se torna possível considerar que a organização dos parlamentares religiosos assume, nesse caso, uma forma partidária dentro do Congresso - mesmo sendo transversal aos partidos políticos -, expressando-se nas ações estratégicas para a eleição de representantes e na atuação das frentes parlamentares para garantir cargos em comissões-chave para sua agenda, o que levaria a um "reordenamento da relação entre sociedade, religião e política" (Ávila, 2006, p. 19). Ainda que possamos estar

\footnotetext{
${ }^{11}$ O trabalho de Mantovani (2014) mostra que, ainda que tivessem linha editorial favorável ao direito ao aborto, na cobertura da campanha os veículos de comunicação contribuíram para anatematizar qualquer passo na direção de sua descriminalização como "suicídio eleitoral".

12 Conferir, por exemplo, o PL 6583/2013, que defende "a entidade familiar", premiando por meio do acesso a recursos e direitos aqueles que se encaixam em uma forma de definição da vida conjugal, sexual, afetiva, parental.
} 
diante de transformações que não são exteriores às democracias contemporâneas, mas parte dos conflitos que as constituem, e que faça sentido refletir sobre respostas "no espírito da inclusividade e não da neutralidade" (Burity, 2008, p. 99), entendemos que a laicidade é ameaçada quando fundamentos religiosos emergem na cena pública como a base para a retração ou o bloqueio a avanços nos direitos individuais.

Por outro lado, o movimento feminista e seus aliados mantiveram o direito ao aborto na sua agenda, sem que necessariamente essa temática ganhasse prioridade na sua atuação junto ao Estado. No ambiente político recente, com as relações de força no período do Partido dos Trabalhadores à frente do governo federal, pode-se levantar a hipótese de que houve estímulo para que fossem priorizadas temáticas como o combate à violência contra a mulher, a ampliação da atenção à saúde feminina ou a busca de reserva de vagas em espaços sociais privilegiados (cotas). Vista como delicada eleitoralmente, pelas razões já expostas, a questão do aborto ficou em posição secundária no debate. Com isso, não se gerava um nicho de opinião pública que colocasse a defesa do direito ao aborto como condição necessária para conceder seu apoio eleitoral a um candidato. A discussão na Câmara dos Deputados reflete essa situação: a condenação ao aborto é prioridade para muitos parlamentares, que encontram nela um instrumento de contato com seu eleitorado, mas a situação não se replica no lado oposto da controvérsia.

\section{O aborto na Câmara dos Deputados}

Para a análise da controvérsia na Câmara dos Deputados, foram lidos e categorizados todos os discursos pronunciados sobre o tema, entre os anos de $1991 \mathrm{e}$ 2014, identificados pela presença das palavras-chave "aborto", "abortamento", "interrupção voluntária da gestação" ou "interrupção voluntária da gravidez"13. Foram identificados, ao todo, 915 discursos com as palavras-chave ${ }^{14}$, número que inclui tanto pronunciamentos inteiramente dedicados ao tema quanto meras menções laterais. Isso corresponde a menos de $1 \%$ do total estimado de discursos no plenário da Câmara, no período sob análise.

O foco nos discursos em plenário permite apreender um aspecto importante da ação parlamentar, que é a construção de sentido sobre o mundo social. A pesquisa se coloca, portanto, na contramão de boa parte da percepção sobre o trabalho parlamentar, até mesmo na literatura acadêmica, que julga que seu principal produto, senão o único, é a lei (ver, por exemplo, Arnold, 1990). O discurso, instrumento pelo qual se constroem e difundem representações do mundo social, é uma atividade igualmente importante no

\footnotetext{
13 Cada discurso foi fichado separadamente por duas integrantes da equipe, de maneira a controlar a subjetividade na interpretação dos quesitos e garantir maior uniformidade de preenchimento.

${ }^{14}$ Após a busca no site da Câmara, foram encontrados 939 discursos. No entanto, 24 foram classificados como irrelevantes: neles, a palavra "aborto" era utilizada apenas como metáfora ou, então, eram meros encaminhamentos de votação. Optou-se por desconsiderar esse contingente.
} 
exercício da atividade dos parlamentares.

Os assuntos privilegiados nos discursos são sensíveis tanto à agenda do momento quanto às prioridades que aquele parlamentar elegeu para seu mandato prioridades que, por sua vez, podem refletir suas conviç̧ões pessoais, mas também uma opção estratégica, que avalia as diferentes oportunidades abertas no campo e estima quais são as expectativas do eleitorado. Os discursos pronunciados em plenário, afinal, dirigem-se simultaneamente aos pares e ao público externo (cf. Miguel e Feitosa, 2009). Uma presença significativa de pronunciamentos contrários ao direito ao aborto, por exemplo, pode indicar que há o entendimento disseminado que essa é uma posição com ressonância na base eleitoral do orador.

Os oradores são, quase todos, homens, o que reflete a baixa presença feminina no parlamento brasileiro. No período sob análise, na Câmara dos Deputados, a proporção de representantes mulheres oscilou em torno dos $8 \%$. Não é surpresa, portanto, que mesmo com maior presença de mulheres, dado o interesse específico da temática, o debate seja dominado pelos homens: eles são os oradores de $86,4 \%$ dos discursos da amostra. O quadro fica pior quando se constata que a questão do aborto é o foco central de $61,7 \%$ dos discursos deles, mas apenas $49,2 \%$ dos discursos delas. Isto é, quando as mulheres intervêm na discussão, o aborto costuma ser apenas um tema, entre outros, que elas abordam no mesmo pronunciamento.

No caso dos partidos, o padrão de atuação no que diz respeito ao aborto não é bem definido ao longo do tempo - embora, nos últimos anos, alguns partidos, como o Partido da República (PR), o Partido Social Cristão (PSC) e o Partido Republicano Brasileiro (PRB), venham concentrando políticos ligados às igrejas evangélicas neopentecostais. Cumpre lembrar que a Câmara brasileira é muito fragmentada. Em algumas das legislaturas sob análise, mais de 20 partidos se encontravam representados. Além disso, a migração de parlamentares eleitos, de um partido para outro, é intensa, mesmo após a resolução do Tribunal Superior Eleitoral, de 2007, que possibilitou punir com a perda do mandato o representante que trocasse de legenda.

$\mathrm{Na}$ base de dados, há uma ligeira concentração de discursos no PT, de centroesquerda, responsável por $22,1 \%$ dos pronunciamentos, um pouco acima do que seria esperado, dado o tamanho de sua bancada. No PT, porém, convivem defensores e adversários do direito ao aborto. Segue, na lista, o Partido da Frente Liberal, depois rebatizado como Democratas (PFL/DEM), de direita, com 11,6\% dos discursos. Predominantemente contra o aborto, o PFL/DEM abrigou, porém, um dos principais defensores desse direito no parlamento brasileiro, o deputado Dr. Pinotti, o que equilibra um pouco a posição média de seus discursos. E, em terceiro lugar, o partido que é herdeiro direto da legenda de sustentação da ditadura militar, que mudou várias vezes de nome no período (PP, PPB, PPR), com 10,2\% dos discursos, quase unanimemente contrários ao direito ao aborto. Na legislatura mais recente que pesquisamos, entre 2011 e 2014, isso muda: os parlamentares que mais falaram sobre aborto são do PSC, que, como dito anteriormente, concentra parlamentares ligados a igrejas evangélicas. Foram 
16 discursos de parlamentares do PSC, todos contrários ao direito ao aborto, seguido do Partido Verde (PV) com 14 discursos (sendo que 13 foram de um mesmo parlamentar, Roberto Lucena, que atua contra o direito ao aborto ${ }^{15}$. Em terceiro lugar, 9 discursos de parlamentares do PDT no período, quase todos com posições contrárias ao aborto.

Os parlamentares que mais falaram sobre o assunto são todos homens e contrários ao direito ao aborto. O primeiro é Luiz Bassuma, já mencionado, com 65 discursos. Líder espírita, ele foi um dos autores da proposta do Estatuto do Nascituro, carro-chefe da campanha contra a interrupção voluntária da gestação. Em seguida, Severino Cavalcanti, que foi do PPB e do PFL, também contrário aos direitos das mulheres, com 40 discursos. Costa Ferreira, que passou por vários partidos de direita, inclusive o confessional Partido Social Cristão (PSC), e Lael Varella, do PFL/DEM, ambos contrários ao aborto, fecham o grupo dos deputados com mais de 30 pronunciamentos na base de pesquisa. O primeiro deputado favorável à legalização do aborto aparece na sétima posição, com 25 discursos (José Genoíno, do PT); a primeira mulher, Marta Suplicy, também do PT, aparece no nono lugar, com 19 discursos. Ao todo, 269 deputados se pronunciaram alguma vez sobre o tema nos anos sob análise. O ranking dos que mais falaram mostra, porém, que a oposição ao aborto é uma prioridade maior, para alguns parlamentares, do que sua legalização o é para os que a defendem.

A distribuição dos discursos ao longo do tempo é bastante irregular, revelando forte concentração em alguns períodos, conforme mostra o Gráfico 1. Entre 1991 e 1999, foram pronunciados 325 discursos sobre aborto no plenário da Câmara dos Deputados, com um pico de 119 pronunciamentos em 1997, quando os parlamentares contrários ao direito ao aborto conseguiram evitar que o Projeto de Lei 20/1991, que regulamentava o atendimento às mulheres nos casos de aborto previsto por lei, na rede pública de saúde, fosse enviado ao Senado. A derrota do projeto suscitou fortes reações dos movimentos feministas, como mencionado anteriormente, levando à conquista da norma técnica do Ministério da Saúde regulamentando o atendimento. Foi, também, o ano em que se deu a visita do papa Wojtyla ao Brasil.

Apenas dez anos depois, o debate voltaria a uma frequência semelhante. Foram 97 discursos em 2007 e 112 em 2008, as duas maiores quantidades de pronunciamentos anuais sobre o tema, atrás apenas de 1997. O quadro era, no entanto, bastante distinto. A observação desses momentos de pico nos discursos nos anos 1990 e nos anos 2000 mostra transformações no equilíbrio e na forma assumida pela controvérsia do aborto no parlamento brasileiro.

A Frente Parlamentar Evangélica atuava com essa denominação desde 2003. Em 2007 estavam formadas outras três frentes parlamentares com o objetivo de obstruir

\footnotetext{
${ }^{15}$ A situação do PV é ilustrativa da falta de coerência programática das legendas brasileiras em relação ao tema. Roberto Lucena pautou sua atuação pela oposição ao direito à interrupção voluntária da gravidez, ao mesmo tempo em que o candidato à presidência da República pelo partido, o ex-deputado Eduardo Jorge, fazia da legalização do aborto um dos carros-chefe de sua campanha. É razoável pensar que Jorge teve liberdade para destoar tanto do discurso imposto aos postulantes à presidência graças à sua condição de candidato "nanico" (obteve 0,6\% dos votos).
} 
avanços no direito ao aborto ou de fazer retroceder a legislação, reduzindo o número de casos previstos para o abortamento legal ou dificultando o acesso das mulheres a esse direito: a Frente Parlamentar contra a Legalização do Aborto, a Frente Parlamentar da Família e Apoio à Vida e a Frente Parlamentar Mista em Defesa da Vida - Contra o Aborto. Essas frentes permitiram reações mais articuladas e focadas às iniciativas favoráveis ao direito ao aborto no âmbito do Executivo, como a Norma Técnica do Ministério da Saúde "Prevenção e tratamento dos agravos resultantes de violência sexual contra as mulheres e adolescentes", de novembro de 1998, que foi reeditada em 2005, passando a excluir a necessidade de Boletim de Ocorrência para atendimento e profilaxia da gravidez em caso de estupro, e a Norma Técnica de "Atenção humanizada ao abortamento", de 2005, que, apoiando-se naquela, determinava o atendimento nos hospitais públicos a mulheres que sofreram violência sexual e desejavam realizar um aborto. Reagiam também a iniciativas no âmbito do Judiciário, como a possibilidade de aprovação da ADPF no 54, apresentada ao STF em 2004 e que levaria de fato, em 2012, a uma decisão favorável ao aborto no caso de má-formação fetal.

Gráfico 1

\section{Discursos com tema "aborto" no plenário da Câmara dos Deputados brasileira, por ano (1991-2014)}

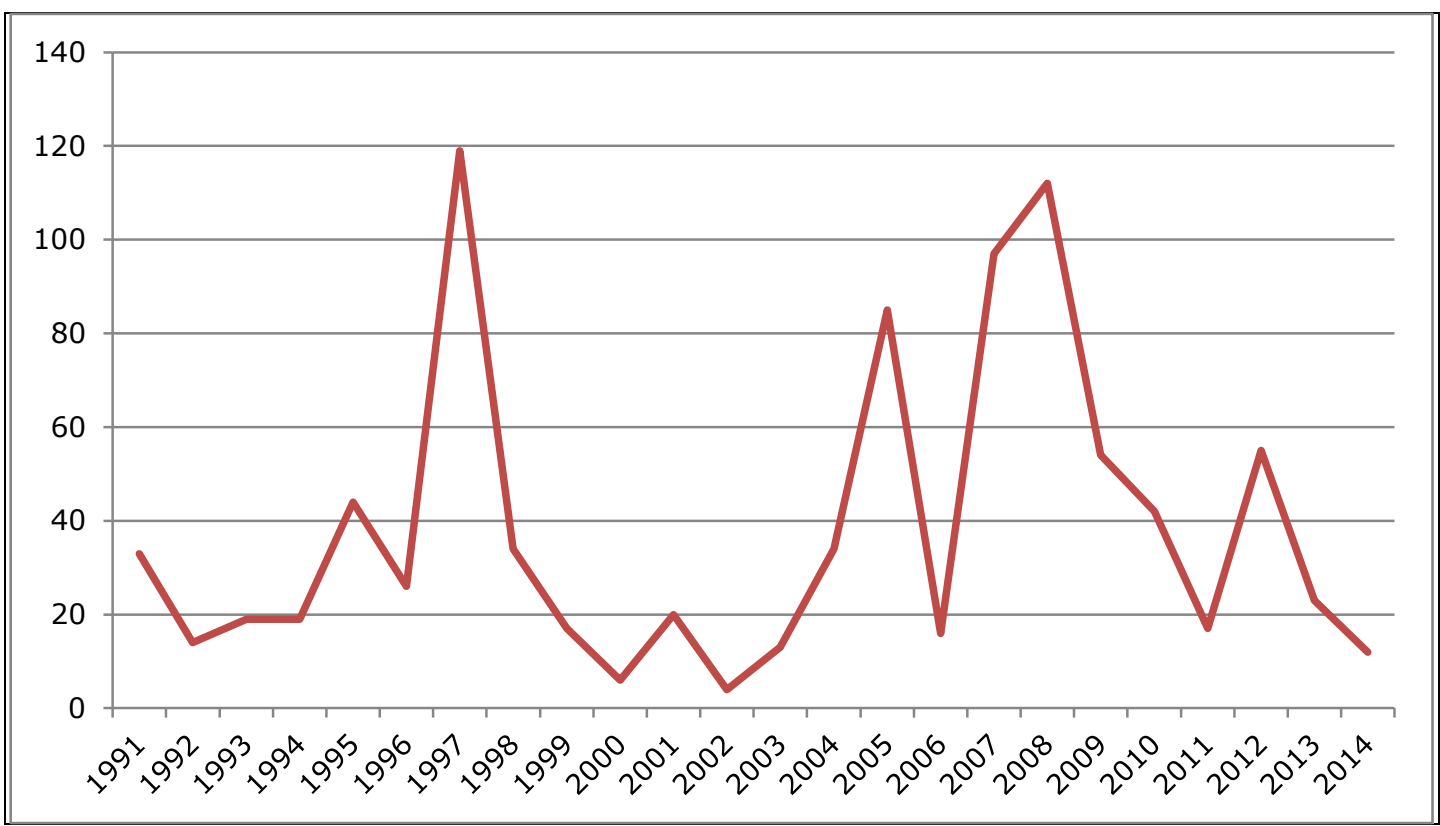

Fonte: Pesquisas "Direito ao aborto e sentidos da maternidade: atores e posições em disputa no Brasil contemporâneo" e "Representação substantiva e gênero no Brasil".

O Gráfico 1 mostra que, embora não haja uma evolução linear e o debate continue sendo pautado por episódios específicos, há uma média anual maior de discursos na segunda metade do período estudado. Mais relevante que a quantidade de pronunciamentos, no entanto, é a distribuição das posições que neles são verbalizadas. 
Ainda que a progressão não seja contínua, é perceptível uma tendência geral de ampliação da maioria de discursos contrários ao direito ao aborto. Assim, o maior percentual de discursos favoráveis à ampliação do direito ao aborto aparece no primeiro ano estudado, 1991, alcançando $39,4 \%$ do total de pronunciamentos (13, num universo de 33 discursos). O fato de que essa parcela nunca tenha ultrapassado o patamar dos $30 \%$ nos anos seguintes, chegando a nenhum discurso no ano de 2011 , cinco discursos em 2012 ( $9 \%$ dos proferidos naquele ano) e novamente nenhum em 2013 e em 2014, indica que os constrangimentos se intensificaram.

A Tabela 1 sumariza os dados relativos à posição dos discursos. O grupo de discursos sem posição é composto, via de regra, por pronunciamentos no qual o aborto foi citado apenas en passant, em meio, por exemplo, a uma listagem de causas de mortalidade de mulheres. Discursos "contra o aborto (de forma genérica)" são aqueles que ecoam os argumentos chamados "pró-vida", mas não apontam especificamente mudanças que deveriam ser introduzidas na legislação para impedir a prática. A categoria "por novas medidas punitivas e/ou de controle" inclui a defesa de propostas como o cadastro de grávidas, o monitoramento ou mesmo banimento de medicamentos com efeito abortivo (como o misoprostol) ou a ampliação das penas aplicadas a mulheres que interrompem voluntariamente a gestação. Por fim, os discursos em favor da educação sexual escapam, muitas vezes, do enfrentamento da questão, preferindo indicar caminhos através dos quais o aborto pretensamente se tornaria desnecessário. Às vezes, esse enquadramento estava combinado com outros, assim como a defesa de medidas punitivas com frequência se associava a uma posição contra o aborto ou favorável à restrição dos casos permitidos por lei. Por isso, cada discurso pôde ser incluído em mais de uma categoria.

Tabela 1

Posição em relação ao direito ao aborto nos discursos pronunciados na Câmara dos Deputados brasileira (1991-2014)

\begin{tabular}{|l|c|c|}
\hline Posição & Discursos & \% \\
\hline A favor da ampliação do aborto legal & 144 & 15,7 \\
\hline A favor da manutenção da lei brasileira & 129 & 14,1 \\
\hline A favor da restrição do aborto legal & 148 & 16,2 \\
\hline Contra o aborto (de forma genérica) & 326 & 35,6 \\
\hline Por novas medidas punitivas e/ou de controle & 132 & 14,4 \\
\hline Pela educação sexual e/ou planejamento familiar & 124 & 13,6 \\
\hline Não se posiciona & 75 & 8,2 \\
\hline
\end{tabular}

Fonte: Pesquisas "Direito ao aborto e sentidos da maternidade: atores e posições em disputa no Brasil contemporâneo" e "Representação substantiva e gênero no Brasil".

Observação: Era possível assinalar até duas respostas.

Nas análises que se seguem, as categorias "a favor da restrição", "contra o 
O DIREITO AO ABORTO NO DEBATE LEGISLATIVO BRASILEIRO: A OFENSIVA CONSERVADORA NA CÂMARA DOS DEPUTADOS

aborto (genérico)" e "por novas medidas punitivas e/ou de controle" foram agrupadas como "posições contrárias ao direito ao aborto". Tais posições aparecem em 566 discursos, isto é, $61,8 \%$ do total. O Gráfico 2 mostra a evolução das três principais posições, ano a ano.

Há duas conclusões que surgem da observação do Gráfico 2. A primeira é que, embora os picos e vales sejam significativos, há uma tendência à ampliação da preponderância das posições contrárias ao aborto. E a segunda é que, nos anos mais recentes, os discursos favoráveis à ampliação do aborto legal têm se reduzido - foram apenas cinco na última legislatura -, cedendo espaço para discursos favoráveis à manutenção da lei. Mais uma vez, identificamos um deslocamento ao longo dos anos, em direção a um maior fechamento do debate, balizado pelas perspectivas conservadoras e retrógradas.

A categoria "a favor da manutenção da lei" tem valor ambíguo: quando é mobilizada contra posições "pró-vida", pode significar um compromisso com o direito ao aborto (e vice-versa). É possível que a ampliação da presença dessa categoria indique que os parlamentares favoráveis aos direitos das mulheres se encontram acuados no debate. Mas é necessário lembrar também que, a partir da decisão do Supremo Tribunal Federal sobre a legalidade do abortamento de fetos portadores de anencefalia, em abril de 2012, houve uma ofensiva para revogar esse avanço por meio de decisão legislativa. Defender a manutenção da lei representaria aqui, também, a oposição a tais manobras.

\section{Gráfico 2 \\ Posições selecionadas de discursos com tema "aborto", no plenário da Câmara dos Deputados brasileira, por ano (1991-2014), como porcentagem do total de pronunciamentos sobre o tema}

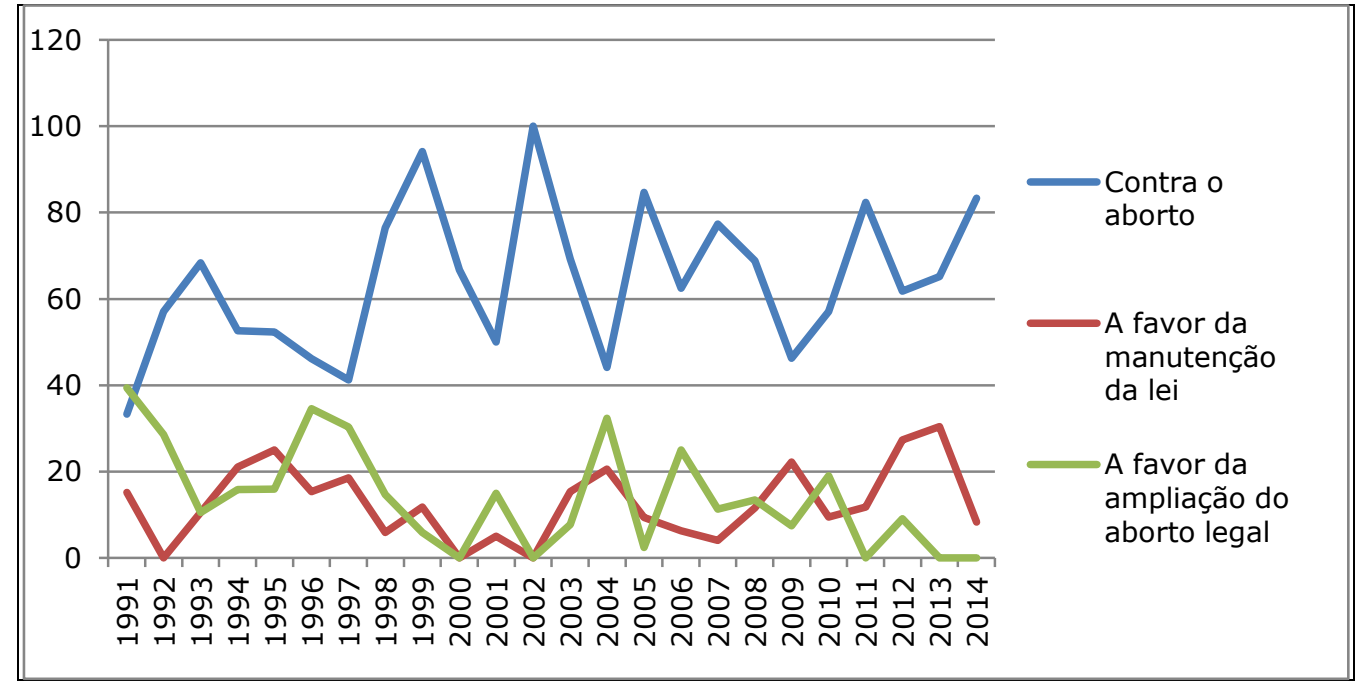

Fonte: Pesquisas "Direito ao aborto e sentidos da maternidade: atores e posições em disputa no Brasil contemporâneo" e "Representação substantiva e gênero no Brasil". 
Nesse debate, embora o número de mulheres parlamentares seja reduzido, o gênero se mostra como variável relevante, como mostra a Tabela 2 - o que, aliás, indica mais uma vez que a sub-representação das mulheres atua no sentido de restringir o debate sobre os direitos das mulheres. Isso não significa que exista um alinhamento automático entre mulheres e posições favoráveis aos direitos sexuais e reprodutivos. Há deputadas que foram ativas na oposição ao aborto, como a deputada Ângela Guadagnin (PT-SP), e também deputados homens sensíveis à necessidade de ampliar o aborto legal, como os já citados José Genoíno e Dr. Pinotti. Ainda assim, é relevante assinalar que quase metade dos discursos pronunciados por mulheres apresentam posição favorável à ampliação do direito ao aborto no Brasil, quer admitindo novas exceções à lei proibitiva, quer descriminalizando de vez a prática. No caso dos homens, apenas pouco mais de um décimo dos discursos adota tal posição. Por outro lado, mais de dois terços dos discursos deles apresentam posições contrárias ao direito ao aborto, mas, no caso das falas de mulheres, são pouco menos de um quarto.

Tabela 2

Posição em relação ao direito ao aborto nos discursos pronunciados na Câmara dos Deputados brasileira (1991-2014), por sexo da ou do parlamentar (\%)

\begin{tabular}{|l|c|c|}
\hline Posição & Homens & Mulheres \\
\hline A favor da ampliação do aborto legal & 10,9 & 46,8 \\
\hline A favor da manutenção da lei brasileira & 14,4 & 12,1 \\
\hline Posições contrárias ao direito ao aborto & 67,8 & 23,3 \\
\hline Pela educação sexual e/ou planejamento familiar & 12,9 & 17,7 \\
\hline Não se posiciona & 7,1 & 15,3 \\
\cline { 2 - 3 } & $n=791$ & $n=124$ \\
\hline
\end{tabular}

Fonte: Pesquisas "Direito ao aborto e sentidos da maternidade: atores e posições em disputa no Brasil contemporâneo" e "Representação substantiva e gênero no Brasil".

Observação: Era possível assinalar até duas respostas.

É um contraste que não se explica pelo fato de que as mulheres na Câmara dos Deputados brasileira estão mais presentes nos partidos de esquerda. Agrupados os partidos em "esquerda", "centro" e "direita", de acordo com a classificação convencional na ciência política brasileira (cf. Krause, Dantas e Miguel, 2010), há, sim, uma concentração da defesa do direito ao aborto na esquerda, mas o contraste é muito menor do que o relacionado ao sexo da ou do parlamentar ${ }^{16}$. Posições contra o aborto são as mais frequentes mesmo entre oradores de partidos de esquerda, alcançando quase metade dos discursos (ver Tabela 3). A defesa do aborto legal, irrisória entre partidos de centro e direita, também é minoritária, com menos de $30 \%$, entre os oradores dos partidos de esquerda.

\footnotetext{
${ }^{16}$ Foram classificados como "esquerda": PCdoB, PDT, PHS, PPS, PROS, PSB, PSOL, PT e PV. Como centro: PMDB e PSDB. Como direita, todos os outros partidos.
} 


\section{Tabela 3}

Posição em relação ao direito ao aborto nos discursos pronunciados na Câmara dos Deputados brasileira (1991-2013), por posição "ideológica" do partido do orador (\%)

\begin{tabular}{|l|c|c|c|c|}
\hline Posição & Esquerda & Centro & Direita & $\begin{array}{c}\text { Sem } \\
\text { partido }\end{array}$ \\
\hline A favor da ampliação do aborto legal & 28,4 & 8,0 & 6,2 & 33,3 \\
\hline A favor da manutenção da lei brasileira & 11,7 & 13,3 & 16,9 & - \\
\hline Posições contrárias ao direito ao aborto & 48,8 & 69,3 & 71,9 & 33,3 \\
\hline $\begin{array}{l}\text { Pela educação sexual e/ou planejamento } \\
\text { familiar }\end{array}$ & 15,6 & 8,7 & 13,5 & - \\
\hline Não se posiciona & 10,3 & 10,0 & 5,2 & 33,3 \\
\cline { 2 - 5 } & $N=377$ & $N=150$ & $N=385$ & $N=3$ \\
\hline
\end{tabular}

Fonte: Pesquisas "Direito ao aborto e sentidos da maternidade: atores e posições em disputa no Brasil contemporâneo" e "Representação substantiva e gênero no Brasil".

Observação: Era possível assinalar até duas respostas.

A posição "ideológica", no entanto, precisa ser relativizada. A atribuição de posições no espectro esquerda-direita é complexa em si mesma, uma vez que reduz a disputa política a uma escala bidimensional, e mais complexa ainda no caso dos partidos brasileiros, que são muito diversos internamente e programaticamente muito frágeis (Miguel, 2010). A análise de cada legenda mostra, como esperado, muita dispersão, mas também algumas constantes. Dois partidos à esquerda, com perfil mais claro, se destacam pela defesa do direito ao aborto: o PSOL e PCdoB, ambos com mais de $60 \%$ dos discursos favoráveis ao direito e nenhum contrário. No PT, 36,1\% dos discursos são favoráveis à ampliação do aborto legal e 44,6\% são contrários ao aborto. Esse percentual, porém, reflete sobretudo a atuação do deputado baiano Luiz Bassuma, que acabou excluído do partido: dos 90 discursos petistas contrários ao direito, 55 foram pronunciados por ele. Vários partidos situados à direita no espectro político não apresentam nenhum discurso favorável à ampliação do direito, mas o mesmo se verifica em duas legendas classificadas como de esquerda: o PHS, com raízes na Igreja Católica "progressista", e o PROS, fundado no final do período sob análise, com composição heteróclita e apenas dois discursos na base de dados. Embora essa não tenha sido a orientação privilegiada na coleta de dados, o que restringe a possibilidade de análise, é possível considerar que o pertencimento a frentes parlamentares, a relação entre parlamentares e denominações religiosas que têm dado prioridade à chamada "agenda moral" na sua atuação pública e ainda a relação entre parlamentares ligados a determinadas igrejas e o apelo eleitoral que eles parecem identificar na agenda conservadora têm peso maior que os partidos políticos na definição das posições no debate.

Mais importante do que essa indicação do perfil partidário dos oradores, porém, é entender como se configura o debate no parlamento brasileiro. Entendemos esse debate 
não como uma "troca deliberativa", destinada à apresentação de razões, com vistas ao convencimento do outro, à busca do consenso esclarecido e à ampliação da qualidade epistêmica de uma eventual decisão, e sim como uma disputa estratégica, relativa aos termos em que se coloca a discussão. De fato, contrariamente à ideia da troca deliberativa racional, mais de dois terços dos discursos não fazem nenhuma menção aos argumentos opostos, ignorando-os por completo. No caso dos discursos contrários ao direito ao aborto, essa tendência é ainda mais acentuada. Assim, o debate se configura como oposição e disputa entre uma ênfase no valor da "vida", entendida de forma metafísica e abstrata, e uma ênfase nos direitos das mulheres e na afirmação de sua capacidade de decisão moral autônoma.

\section{Os argumentos nos discursos}

A partir de pré-testes com amostras da base de discursos, foi elencada uma lista de argumentos mobilizados no debate, que então serviu de guia para a classificação levada a cabo pela equipe de pesquisa. Foram identificados os diversos argumentos presentes em cada pronunciamento e, então, qual deles ocupava a posição principal na construção da exposição. Com isso, buscou-se entender os quadros de sentido em que se colocava o debate sobre o direito ao aborto na Câmara dos Deputados brasileira.

Entre os argumentos favoráveis ao direito ao aborto, destacam-se: (1) a ideia de que o aborto, uma das maiores causas de internação hospitalar e mortalidade de mulheres em idade fértil no Brasil, deve ser tratado como questão de saúde pública; (2) o apelo à liberdade individual das mulheres, por vezes com menção expressa ao direito da mulher quanto ao controle sobre seu próprio corpo; (3) o fato de que a proibição do aborto é um fator de injustiça social e discriminação, já que as brasileiras ricas em geral têm acesso a formas seguras de interrupção da gravidez, enquanto as pobres ficam à mercê de clínicas clandestinas, métodos caseiros ou, ainda, ao tráfico do misoprostol, de procedência duvidosa e tomado de maneira incorreta; (4) argumentos jurídicos, em particular interpretações da Constituição brasileira que garantiriam o direito ao aborto e a defesa do cumprimento da legislação, com atendimento a mulheres em busca de abortamento legal na rede pública; e (5) argumentos ligados ao valor da laicidade do Estado, vendo a oposição ao direito ao aborto como indício de uma influência religiosa inadequada sobre o Estado brasileiro. Uma pequena parcela de discursos utilizou ainda argumentos macroeconômicos, ligando o aborto legal à redução nos custos da rede de saúde.

A prevalência dos argumentos de saúde pública não é surpreendente. Diante de um adversário que se apropriou do discurso da defesa da vida, a estratégia mais evidente é indicar os efeitos reais, sobre vidas humanas, da proibição do aborto. 0 argumento da injustiça social, sobre a variação dos efeitos da lei proibitiva de acordo com a posição de classe da mulher, está frequentemente associado a eles. Mas é importante ressaltar a presença de argumentos de natureza política, que colocam a 
discussão no terreno dos direitos, do acesso à cidadania e da vinculação entre laicidade e democracia. Cabe anotar ainda que $10,4 \%$ dos discursos favoráveis ao direito ao aborto não trazem nenhum argumento, simplesmente externando sua posição em defesa da ampliação da possibilidade legal de interrupção voluntária da gravidez.

Já os argumentos contrários ao direito ao aborto tiveram, como categoria principal, conforme esperado, a noção de um direito à vida que seria inviolável e teria primazia absoluta sobre outros direitos. Mas é um argumento que se define mobilizando outros argumentos - daí a configuração constante dos discursos pela presença simultânea de mais de um argumento. Afinal, é necessário determinar que vida é essa e onde estão fundadas a inviolabilidade e a primazia desse direito. Estão fundadas: (1) nos dogmas religiosos; (2) em argumentos morais que, ainda que muitas vezes ecoem uma moralidade de fundo místico, evitam utilizar conceitos como "alma" ou a intervenção de algum ser sobrenatural; (3) na opinião pública, pela ideia de que o aborto não deve ser permitido porque surveys mostram uma maioria da população brasileira contrária à concessão do direito; e (4) em argumentos jurídicos, em geral, decorrentes de uma definição de "vida" iniciada na concepção, daí afirmando a extensão da proteção constitucional à vida também aos não nascidos, assim definidos como "pessoas". Há ainda a presença marginal, mas não irrelevante, de discursos que se posicionam contra o aborto por vê-lo como parte de uma estratégia imperialista de contenção da população dos países do Sul.

Também entre esses discursos, 11,5\% não apresentam qualquer argumento. Argumentos que se querem científicos - determinando, por exemplo, que o início da vida se daria na concepção - estão mais presentes nos discursos contrários ao direito ao aborto ( $14,1 \%$ dos casos) do que nos favoráveis (apenas $4,2 \%$ dos casos). Não são, no entanto, um espaço central de debate. Os números deixam claro que o polo contrário ao aborto tem no apelo à religião um elemento central de sua estratégia argumentativa.

De fato, os argumentos mais mobilizados no conjunto dos discursos foram o da "inviolabilidade da vida" e o "religioso", que convergem em posições contrárias ao direito ao aborto. Como mostra a Tabela 4, foram os principais argumentos em 387 pronunciamentos, $42,3 \%$ do total. Cumpre observar que, na tabela, estão incluídos discursos - raros, mas não inexistentes - que fazem uso surpreendente dos argumentos, defendendo o direito ao aborto com alegações religiosas ou mobilizando a ideia de autonomia da mulher para justificar a criminalização da prática. 
Tabela 4

Argumento principal nos discursos sobre aborto na Câmara dos Deputados, entre 1991 e 2014

\begin{tabular}{|l|c|c|}
\hline Argumento principal & N & \% \\
\hline Direito à vida & 282 & 30,8 \\
\hline Dogmas religiosos & 105 & 11,5 \\
\hline Saúde pública & 94 & 10,3 \\
\hline Jurídicos & 55 & 6,0 \\
\hline Morais (não explicitamente religiosos) & 43 & 4,7 \\
\hline Opinião pública & 43 & 4,7 \\
\hline Liberdade individual & 35 & 3,8 \\
\hline Estratégia imperialista & 19 & 2,1 \\
\hline Científicos & 17 & 1,9 \\
\hline Usurpação de poderes do Legislativo & 16 & 1,7 \\
\hline Injustiça social & 12 & 1,3 \\
\hline Laicidade do Estado & 7 & 0,8 \\
\hline Controle sobre o próprio corpo & 4 & 0,4 \\
\hline Macroeconômicos & 3 & 0,3 \\
\hline Outros & 16 & 1,7 \\
\hline Sem nenhum argumento & 164 & 17,9 \\
\hline$N=$ & 915 & 100 \\
\hline
\end{tabular}

Fonte: Pesquisas "Direito ao aborto e sentidos da maternidade: atores e posições em disputa no Brasil contemporâneo" e "Representação substantiva e gênero no Brasil".

$\mathrm{Na}$ Tabela 4, a categoria "sem nenhum argumento" é inflada pelo contingente de discursos que não apresentam posição sobre o tema, aqueles que apenas citam de passagem a questão do aborto. Os argumentos na categoria "outros" são aqueles que não se encaixavam nas categorias principais, como o risco de abortamento seletivo de meninas ou a necessidade de "proteger a mulher do arrependimento" (por ter interrompido a gravidez). Em boa parte, são um testemunho da imaginação criativa dos deputados: mulheres civilizadas não fazem aborto (Luiz Bassuma, PT-BA, 19 mar. 2007); a legalização do aborto aumentaria a prostituição infantil (Pastor Frankembergen, PTBRR, 2/5/2005); o aborto legal sobrecarregaria o sistema público de saúde, impedindo que os médicos atendessem os doentes (Philemon Rodrigues, PRB-MG, 27 out. 1997).

O recurso ao "direito à vida", que é o argumento mais presente nos pronunciamentos, visa muito mais impedir a discussão sobre o aborto do que estimulála. Nele, o abortamento voluntário é equiparado ao assassinato, ponto que está sempre presente nos discursos dos anos 1990, levando à afirmação de que "a questão do aborto, na verdade, nem deveria ser votada. É o mesmo que votar sim ou não à vida. Isso não se vota. O fato de colocá-la em votação já é um desrespeito à vida. É colocar a vida em roleta russa" (deputado Serafim Venzon, PDT-SC, 19 set. de 1995). 
Um passo ulterior, que aparece também nos anos 1990, é o esforço para fundir a temática do aborto à dos direitos humanos, sempre partindo da noção de "direito à vida". O primeiro discurso que recorre à noção de direitos humanos no corpus analisado foi pronunciado em 1993, inaugurando uma ideia que se repetiria ao longo dos anos, de que o direito à vida é o "maior e mais inviolável" de todos os direitos humanos (deputado João Teixeira, PL-MT, 15 abr. 1993). Essa estratégia ganharia força novamente em meados da década de 2000 e, de maneira aguda, na discussão do III Plano Nacional de Direitos Humanos (PNDH-3), em 2010. Entre as propostas de ações governamentais para garantir os direitos das mulheres, ele incluiu o "alargamento dos permissivos para a prática do aborto legal, em conformidade com os compromissos assumidos pelo Estado brasileiro no marco da Plataforma de Ação de Pequim" (item 179, p. 279). Trata-se, assim, de disputas que têm expressão no Congresso, ainda que as posições favoráveis à ampliação do direito ao aborto não estejam necessariamente sendo colocadas ali. 0 PNDH-3 é um exemplo de que houve um entendimento de atores políticos favoráveis a esse direito de que outras arenas seriam mais propícias para avançar nessa direção.

$\mathrm{Na}$ década de 2000, com o deslocamento do debate para um enquadramento mais conservador, o direito ao corpo seria trazido ao debate, mas como alvo de quem mobilizava o argumento da defesa da inviolabilidade da vida. O discurso feminista passaria a ser tematizado mais abertamente, porém da perspectiva daqueles que a ele se opõem, com o objetivo de desconstruí-lo. Em uma síntese do que foi repetido em vários momentos, afirmou-se que "é fato que a mulher tem direito sobre seu corpo, mas não sobre a vida de outra pessoa" (Costa Ferreira, PSC-MA, 2 ago. 2005) e que a liberdade de uma pessoa - "a liberdade que uma mulher tem de decidir sobre o seu corpo" - não poderia ser conquistada à custa do direito à vida de outras pessoas (Henrique Afonso, PT-AC, 11 maio 2007). Há um silogismo implícito, de que o direito à vida possui primazia sobre qualquer outro direito e, sendo assim, o direito individual da mulher não se sobrepõe ao do feto.

Em todos os momentos, é mobilizada, de forma implícita ou explícita, a noção de que a vida se inicia na concepção. Trata-se de um elemento fundamental na visão que funda o discurso contrário ao direito ao aborto. Sua aparente obviedade, no entanto, esconde dois problemas sérios e interligados (sobre a questão, ver Boltanski, 2004; Kaplan, 2008). Primeiro, nem tudo que está vivo (e é humano) tem direito à vida: um tecido do corpo certamente está vivo, mas não possui um direito à vida per se. O que gera o direito (e esse é o segundo problema) é o estatuto de indivíduo, que não decorre automaticamente da presença dos atributos "vivo" e "humano". Em geral, a lei determina que tal estatuto é concedido no momento do nascimento, mas a discussão filosófica sobre a questão é intensa, podendo colocar a fronteira antes - por exemplo, no surgimento da senciência, o predicado de sentir dor ou prazer, que nos fetos humanos ocorreria por volta do quarto ou quinto mês de gestação - ou depois, com a autoconsciência ou a capacidade de entender a si mesmo como um ser dotado de 
continuidade, o que corresponderia a uma criança com alguns anos de vida ${ }^{17}$.

Justamente porque a mera afirmação do direito à vida e a definição de que a vida começa na concepção não liquidam a questão, os grupos antiabortistas avançaram para a defesa da aprovação de uma norma legal que garantisse aos não nascidos o mesmo conjunto de direitos garantidos aos nascidos. Isso levou, em 2005, à proposição do chamado Estatuto do Nascituro, cujo objetivo era transferir, na letra da lei, o momento do início da vigência dos direitos individuais - do nascimento para a concepção. $O$ propósito era, evidentemente, impedir qualquer avanço na direção da legalização do aborto, que seria então oficialmente equiparado ao assassinato. De fato, mesmo um dos casos permitidos pela lei brasileira, o aborto em caso de gravidez resultante de estupro, seria bloqueado, caso a concepção fundante do Estatuto do Nascituro fosse aceita ${ }^{18}$, em um dos principais exemplos de como as investidas presentes no Congresso procuram definir retrocessos em relação às normas vigentes. O outro caso previsto na lei, o de risco de vida para a gestante, seria tolerado no máximo como uma forma de "legítima defesa".

Há uma sobreposição forte entre a noção de que a vida existe a partir da concepção, tal como mobilizada pelo discurso contrário ao direito ao aborto, e a ideia de que a vida é criação de Deus e só pode ser retirada por Deus, que é o eixo do argumento religioso. De fato, as discussões referidas antes, sobre o surgimento da senciência ou da autoconsciência, perdem valor caso se considere que a concepção coincide com a infusão de uma "alma" única, naquele zigoto, pelo Todo-Poderoso em pessoa ${ }^{19}$. Embora existam variações nos fundamentos e dogmas presentes em diferentes religiões, esse fundo religioso atravessa os discursos e é indissociável da noção de que a concepção gera o direito à vida. Na classificação feita na pesquisa, porém, só foram considerados "religiosos" os argumentos que faziam menção explícita a Deus ou outros seres sobrenaturais, a textos sagrados ou à palavra de autoridades eclesiásticas ou de documentos doutrinários, como a encíclica Evangelium Vitae ${ }^{20}$, de 1995, marco da ofensiva vaticana contra a interrupção voluntária da gravidez.

Quando se considera também sua presença como argumentos secundários, os argumentos "religiosos", mesmo nessa acepção mais rigorosa, estão presentes em quase um terço dos discursos. Os argumentos da "inviolabilidade do direito à vida", em mais da metade deles. Mas uma perspectiva diacrônica mostra que, embora permaneçam frequentes, os argumentos "religiosos" têm recuado.

\footnotetext{
17 Sem focar exclusivamente na questão do aborto e do estatuto de indivíduo, um bom resumo do debate filosófico se encontra em Warren (1997).

${ }^{18}$ Os grupos antiabortistas recuaram em relação a esse ponto, optando pela introdução de incentivos às vítimas da violência sexual que optassem por levar a gravidez a termo (a "bolsa estupro").

${ }^{19}$ Durante muito tempo, a própria doutrina católica admitia que a alma era insuflada apenas em momentos posteriores da gestação (cf. Kaplan, 2008), mas essa discussão não será levada adiante aqui.

${ }^{20}$ Essa encíclica mobiliza a genética moderna para afirmar que desde a fecundação do óvulo já existe vida humana, que não é a do pai nem a da mãe, mas uma vida própria, com suas características já determinadas.
} 
Levando em conta apenas os discursos contrários ao aborto, observa-se que, no período 1991-2002 (isto é, da 49a à 51a legislaturas), considerados todos os argumentos mobilizados pelos oradores, o recurso à religião se encontra em $65,6 \%$ dos pronunciamentos, mas esse percentual baixa para 30\% no período 2003-2014 (52a à $54^{a}$ legislaturas). Isolados os argumentos principais, o recurso à religião nos pronunciamentos contrários ao aborto desce de 25,3\% no período 1991-2002 para $11,3 \%$ no período 2002-2014. Isso parece indicar que a defesa da laicidade do Estado encontra alguma ressonância entre os agentes políticos e que mesmo a bancada religiosa está entendendo que deve apresentar publicamente sua posição em termos que não privilegiem seu fundamento confessional ${ }^{21}$. Esse deslocamento na construção pública das posições não incorpora o valor da laicidade do Estado, de fato, mas procura contorná-lo.

$O$ recurso a fundamentos e crenças religiosas aparece nos discursos, por vezes, como identificação do orador, que sustenta sua posição no debate por meio da enunciação de sua filiação religiosa. Há diferenças, porém. Quando um parlamentar afirma que "sou um cristão e um católico, sou contra a pena de morte para os inocentes" (Osmânio Pereira, PSDB-MG, 25 nov. 1997), é possível ler sua fala como uma indicação de que sua atuação política é definida por um conjunto de valores morais associados à igreja da qual participa. Há falas, no entanto, em que a crença religiosa aparece como fonte não de valores, mas de verdades dogmáticas que precisam ser respeitadas pela decisão política: "Sou um homem de Deus, que acredita na verdade e na vida como um dom supremo. Por isso, subo à tribuna neste dia para repudiar a famigerada intenção de legalização do aborto" (Costa Ferreira, PSC-MA, 20 jun. 2008). Por fim, a igreja à qual pertence o orador pode ser chamada à posição de interlocutora privilegiada, em paridade com o Estado: "Esse debate não pode tomar outro caminho a não ser o da discussão com a Igreja Católica, principalmente, a qual frequento, para não permitir que se estabeleça na Constituição o assassinato da vida e do espírito" (Paulo Lima, PMDB-SP, 8 dez. 2005).

Ainda que, nos três casos, haja um apelo religioso, eles possuem estatuto diferente. O primeiro circunscreve a posição do parlamentar ou, para usar a terminologia de Weber, sua "ética da convicção", aquela que precisa existir em paralelo à ética da responsabilidade para que o político se configure um "homem genuíno" (Weber, 1985, p. 22). O segundo indica que uma verdade revelada é o fundamento absoluto de todas as ações humanas; é, portanto, um discurso de caráter fundamentalista. O terceiro põe em xeque diretamente a laicidade do Estado (algo que é também uma derivação lógica do argumento fundamentalista).

Outros discursos não evocam a filiação do orador, mas apelam diretamente para textos sagrados ou para dogmas da fé como forma de encerrar a discussão, o que

\footnotetext{
${ }^{21}$ A ideia da defesa da vida também está presente nos argumentos jurídicos, mobilizados em $25,6 \%$ dos discursos contrários ao direito ao aborto, que recorrem ao art. $5^{\circ}$ da Constituição, e, principalmente, aos argumentos "científicos", mobilizados em 14,1\% desses pronunciamentos, nos quais os parlamentares utilizam a ciência para dar legitimidade e retirar o caráter religioso da afirmação de que a vida começa na concepção.
} 
LUIS FELIPE MIGUEL; FLÁVIA BIROLI; RAYANI MARIANO

também permite caracterizá-los como fundamentalistas - a verdade é definida anteriormente aos embates e provém de Deus, ainda que nem sempre sejam evocadas religiões específicas, textos considerados sagrados por elas ou documentos que orientam as posições relativas ao aborto. Em alguns deles, fica patente a recusa à validade de posições e discursos não religiosos:

A vida é um dom de Deus, dado por Deus, e nenhum homem, nem mulher, nem médico, nem parlamentar pode chegar aqui e defender o aborto. É uma vergonha, uma ignomínia (João de Deus Antunes, PDS-RS, 26 mar. 1991).

Homem de formação religiosa que sou, não posso de forma alguma compactuar com um ato que atenta contra a vida, valor supremo concedido por Deus (Costa Ferreira, PP-MA, $1^{\circ}$ set. 1994).

Ferem a Constituição, desonram a família e afrontam Deus (Philemon Rodrigues, PTB-MG, 19 ago. 1997).

A verdade é que Deus se incomoda com a vida. Ele é o Senhor da Vida (pastor Pedro Ribeiro, PMDB-CE, 10 jul. 2008).

No Brasil, tenta-se de todas as maneiras encontrar subterfúgios para autorizar o aborto, formalizando interesses escusos em nome de uma falsa liberdade. São teses que tentam justificar o injustificável, pois a Lei de Deus é só uma, e vale para todos. Deus ama a todos, mas abomina o pecado" (pastor Marco Feliciano, PSC-SP, 9 out. 2012).

Todo sopro de vida é, na verdade, a expressão da vontade de Deus e a realização de seu plano superior destinado a cada pessoa. Interromper essa ligação é um crime não só com o próximo, mas também consigo mesmo. Por isso, somos absolutamente contra o aborto seja qual for a sua circunstância (Gladson Cameli, PP-AC, 28 maio 2014).

Como mostram os exemplos, esse tipo de discurso não desapareceu nas legislaturas mais recentes. Mas os dados agregados mostram que ele se tornou menos recorrente. Uma explicação possível se liga à ambiguidade de destinatários do discurso parlamentar, já referida. A evocação direta da vontade divina é estratégica para deputados com base eleitoral confessional, que portanto nela insistem para mostrar seu compromisso religioso no exercício do mandato. Mas se mostra incapaz de agregar a maioria dos votos da casa e, portanto, são necessários outros tipos de discurso para atingir os pares.

Numa perspectiva antagônica a essa, o argumento da "saúde pública" esteve presente em $61,8 \%$ dos discursos favoráveis à ampliação do aborto legal e foi o principal argumento em $40,3 \%$ deles, enquanto os discursos que recorreram à "liberdade individual" e/ou ao "controle da mulher sobre seu corpo" aparecem em 50\% dos 
discursos, mas como argumento principal em apenas 22,9\% deles. O argumento da saúde pública desloca a discussão do terreno dos princípios para o das consequências práticas - é um discurso pragmático, que busca confrontar o valor da vida do feto, brandido por aqueles que são contrários ao direito ao aborto, com outras vidas, as vidas das mulheres que são vítimas do abortamento clandestino.

Já o discurso da liberdade individual e do controle sobre o próprio corpo enfatiza o reconhecimento das mulheres como agentes morais autônomas. É possível interpretar a menor mobilização de argumentos relativos à autonomia das mulheres e ao seu direito a decidir sobre seu corpo como um indício do ambiente desfavorável à afirmação da plena autonomia das mulheres, como indivíduos e como cidadãs dotadas da capacidade integral de tomar suas próprias decisões. O avanço da ideologia familista, que naturaliza noções convencionais da família e do papel da mulher, é um elemento importante na construção desse ambiente. Mas é possível, também, considerar que esse ambiente se nutra desse recuo: a opção por evitar o enfrentamento direto, por parte das defensoras dos direitos das mulheres, contribui para conformar o debate na forma retrógrada atual.

Cabe lembrar que, no contingente relativamente pequeno de discursos em que existem contra-argumentos, isto é, em que fundamentos da posição adversária são criticados, as ideias de liberdade individual das mulheres e de controle sobre o corpo estão muito presentes. De fato, 139 dos 274 discursos com presença de contraargumentos - 50,7\% deles - se dedicam a condenar tais noções. Em suma, no plenário da Câmara dos Deputados há a situação inusitada de que a autonomia da mulher, eixo central do movimento feminista, aparece muito mais na voz de seus críticos do que de seus (potenciais) defensores.

Por outro lado, o argumento da "saúde pública" também foi mobilizado numa parcela não desprezível dos discursos contrários ao aborto (53 pronunciamentos, sendo o argumento principal em 15 deles). Reservando para as mulheres uma posição de vítima, eles argumentavam que o aborto possui consequências tanto físicas quanto psicológicas, e afirmavam que, devido a essas consequências, deveria haver mais medidas de controle e mais punição para que o aborto ilegal não fosse realizado. A obstrução do direito ao aborto se faria em benefício das mulheres, numa definição que contraria frontalmente o entendimento de que são indivíduos autônomos, capazes de escolhas sobre suas próprias vidas, e de que sua integridade física e psíquica é comprometida quando esse direito lhes é recusado.

\section{Conclusão}

Apesar da frustração de militantes e ativistas, que buscam avanços mais rápidos e definitivos e mesmo garantias para que a legislação atual seja cumprida, o debate sobre o direito ao aborto no Brasil não está parado. Há muito mais movimentação sobre o assunto hoje do que nas décadas que se seguiram à edição do Código Penal de 1940, que continua a regular a matéria. No debate eleitoral, na internet, na imprensa, em 
manifestações nas ruas e mesmo no Congresso, o tema do aborto tem ganhado destaque. Esse destaque, porém, não significa necessariamente maior abertura para discutir o direito ao aborto e nem sempre significa uma explicitação maior dos conflitos, com diferentes perspectivas definindo a controvérsia.

Na Câmara dos Deputados, essa controvérsia teve sua gramática alterada entre 1991 e 2014. A pesquisa mostra que, aos avanços que se apresentaram a partir do final dos anos 1990 - limitados, mas não desprezíveis, como a pressão crescente para que a rede pública de saúde atenda aos casos de aborto previstos em lei e a possibilidade de interrupção da gravidez de fetos inviáveis -, tem feito frente uma reação mais articulada.

Cresceu o ativismo dos grupos que, por motivos religiosos, são contrários à descriminalização do aborto. É possível sustentar a hipótese de que tem sido ativo e ampliado também, no Brasil, no mesmo período, o ativismo feminista pelos direitos das mulheres. Mas esse último não encontra correspondente no Congresso da mesma forma que o dos grupos contrários ao direito ao aborto, cuja atuação se avolumou tanto pelo fato de que há hoje mais parlamentares para quem essa agenda é prioridade - ao menos na construção da sua imagem pública - quanto pelo fato de que sua articulação tem sido mais efetiva e mais focada. A ação das frentes parlamentares (a evangélica e aquelas que se definem como defensoras da família e da vida), o maior número de proposições que, se aprovadas, representariam retrocessos na legislação atual e os esforços para a ocupação de espaços nas comissões pelas quais essas proposições tramitam são formas e efeitos importantes dessa articulação hoje. A hipótese de que o padrão do debate se alterou entre os anos 1990 e 2000 é confirmada pela análise dos discursos proferidos em plenário e pode ser resumida pela ideia de que hoje são os conservadores que balizam o debate, restando àquelas e àqueles que defendem os direitos das mulheres reagir à reação, isto é, agir para barrar os retrocessos em curso.

A análise dos discursos mostra isso claramente. Os picos das discussões nos anos 1990 remetem a tentativas de avanço na legislação e são, ainda, marcados por manifestações mais numerosas e mais abertas em defesa dos direitos das mulheres. Já nos anos 2000, esses picos expõem a ação mais articulada de parlamentares ligados a diferentes denominações religiosas e o recuo nas posições favoráveis ao direito ao aborto. Elas se expressam com frequência menor e praticamente silenciam sobre a relação entre aborto, autonomia e cidadania das mulheres. Nos anos 2000, a autonomia das mulheres seria evocada sobretudo como contra-argumento nos discursos contrários ao direito ao aborto. No mesmo contexto em que se tornou possível uma ação não apenas conservadora mas francamente retrógrada na Câmara dos Deputados, ampliaram-se os constrangimentos para a expressão da defesa dos direitos das mulheres no âmbito reprodutivo, especialmente por meio de uma terminologia que evidenciasse que a criminalização do aborto restringe sua cidadania.

Embora existam mulheres que tenham atuado na Câmara contra o direito ao aborto e não seja possível estabelecer uma relação automática entre sexo da/o parlamentar e posição nesse debate, é entre elas que esteve presente com maior 
frequência a expressão de posições favoráveis ao aborto. No período analisado, como se sabe, a representação das mulheres na Câmara federal permaneceu abaixo dos $10 \%$. Os dados da pesquisa permitem, ao menos a título de hipótese, estabelecer uma correlação entre a baixa representação das mulheres e a presença restrita da problemática do aborto de uma perspectiva orientada pelas experiências destas e pelo valor da autonomia.

Trata-se, nos dois casos - o do balizamento crescente do debate pelas posições conservadoras e o da variável de gênero na organização das controvérsias -, de uma dinâmica que não se produz ou se explica apenas pelo que se passa dentro do Congresso. Estabeleceram-se novas relações de força, que implicam constrangimentos maiores para parlamentares que se posicionem a favor do direito ao aborto. Isso levou a uma inequívoca retração das posições progressistas no debate. Esse equilíbrio está relacionado tanto às novas estratégias de várias igrejas para sua ação na esfera política quanto às ambiguidades que marcaram os governos do Partido dos Trabalhadores desde 2003. A maior permeabilidade do Executivo aos movimentos sociais, entre eles os movimentos feministas, conviveu com alianças políticas com setores conservadores, que pressionaram o governo, crescentemente, limitando a implementação de políticas relacionadas aos direitos reprodutivos e sexuais.

Assim, os discursos proferidos na Câmara entre 1991 e 2014 ecoaram, crescentemente, argumentos morais e religiosos, ou codificados de acordo com o discurso da Igreja Católica e de parte importante das igrejas pentecostais e neopentecostais. Isso não significa que tenham se ampliado os argumentos abertamente religiosos, uma vez que, como mostram os dados analisados, a laicidade do Estado parece ser levada em conta, ao mesmo tempo que é contornada por meio de uma defesa incondicional da vida que, em muitos momentos, é apresentada como autoevidente. Diferentemente do que se deu na década de 1990, nos anos 2000 se tornou menos frequente a relação aberta entre o direito à vida e o argumento de que a origem da vida é sobrenatural e, portanto, não pode responder à vontade dos indivíduos - no caso, das mulheres. $O$ foco nos direitos do embrião ou feto se ampliaria.

Para entender o quadro em que o debate se redefine, é importante levar em conta os incentivos presentes nas campanhas eleitorais e a atuação do Poder Executivo federal em relação à pauta do movimento feminista de forma mais ampla. A ofensiva religiosa junto à opinião pública converge para o reposicionamento das forças políticas mais conservadoras. As políticas sociais compensatórias dos governos petistas corroeram parte de seus bastiões eleitorais tradicionais e a ênfase na chamada "agenda moral" pode favorecer a reconquista de tais bases. Com a consolidação de tal ambiente de disputa discursiva, os custos da sustentação do direito ao aborto se mostram cada vez mais altos. Um cálculo imediato de custo-benefício, por parte das posições feministas, tornava razoável a decisão de, na discussão parlamentar e eleitoral, privilegiar outros itens da agenda e concentrar a defesa desse direito em outras arenas, aparentemente mais "técnicas" e menos sensíveis à pressão da opinião pública, como o Ministério da Saúde e 
o STF. Mesmo no caso do Poder Executivo, uma pressão maior pela ampliação do direito ao aborto parecia fadada ao fracasso, devido ao peso da bancada parlamentar contrária, podendo colocar em risco o avanço em outras políticas públicas importantes (atenção à saúde da mulher, combate à violência contra as mulheres, cotas eleitorais).

O resultado líquido é o fechamento do debate nas esferas institucionais, que o golpe de 2016 apenas intensificou. A circunscrição crescente do debate pelos sentidos que prevalecem nos discursos morais e religiosos, colocados em circulação por instituições que atuam politicamente contra o direito ao aborto, reduz a possibilidade de ver o aborto como uma questão de cidadania. Parlamentares simpáticos à legalização da interrupção voluntária da gravidez encontram pouco ou nenhum incentivo para priorizar tal tema em sua ação política. A solução do impasse certamente passa pela intensificação da pressão extraparlamentar pelo direito ao aborto, criando um ambiente social mais favorável a iniciativas que revoguem as restrições hoje presentes no ordenamento legal brasileiro.

\footnotetext{
Luis Felipe Miguel - Professor do Instituto de Ciência Política da Universidade de Brasília, onde coordena o Grupo de Pesquisa sobre Democracia e Desigualdades (Demodê), e pesquisador do CNPq. E-mail: <luisfelipemiguel@gmail.com>.

Flávia Biroli - Professora do Instituto de Ciência Política da Universidade de Brasília, onde coordena o Grupo de Pesquisa sobre Democracia e Desigualdades (Demodê), e pesquisadora do CNPq. E-mail: <flaviabiroli@gmail.com>.
}

Rayani Mariano - Doutoranda em Ciência Política na Universidade de Brasília.

$<$ E-mail: rayanimar@hotmail.com>.

\section{Referências bibliográficas}

ARNOLD, R. D. The logic of congressional action. New Haven: Yale University Press, 1990.

ÁviLA, M. B. M. Reflexões sobre laicidade. In: BATISTA, C.; MAIA, M. (orgs.). Estado laico e liberdades democráticas. Recife: Articulação de Mulheres Brasileiras, Rede Nacional Feminista de Saúde, SOS Corpo, Instituto Feminista para a Democracia, 2006.

Biroli, F. Família: novos conceitos. São Paulo: Editora da Fundação Perseu Abramo, 2014.

BoltanSKI, L. La condition foetale: une sociologie de l'engendrement et de l'avortement. Paris: Gallimard, 2004.

BRITO, R. "Grupo prepara ação no STF para permitir aborto em caso de zika" [online]. O Estado de S. Paulo, 12 fev. 2016. Disponível em: <http://saude.estadao.com.br/noticias/geral,grupo-preparaacao-no-stf-para-permitir-aborto-em-caso-de-zika,10000016037>. Acesso em: 13 fev. 2016.

BURITY, J. A. "Religião, política e cultura". Tempo social, São Paulo, vol. 20, no 2, p. 83-113, nov. 2008.

Diniz, D.; Medeiros, M. "Aborto no Brasil: uma pesquisa domiciliar com técnica de urna". Ciência \& Saúde Coletiva, Rio de Janeiro, vol. 15, nº 15, p. 959-966, jun. 2010. 
O DIREITO AO ABORTO NO DEBATE LEGISLATIVO BRASILEIRO: A OFENSIVA CONSERVADORA NA CÂMARA DOS DEPUTADOS

HTUn, M. Sex and the state: abortion, divorce, and the family under Latin American dictatorships and democracies. Cambridge: Cambridge University Press, 2003.

KAPLAN, F. L'embryon est-il un être vivant? Paris: Le Félin, 2008.

KRAuse, S.; DAntas, H.; Miguel, L. F. (orgs.). Coligações partidárias na nova democracia brasileira: perfis e tendências. São Paulo: Editora Unesp; Rio de Janeiro: Konrad Adenauer Stiftung, 2010.

LOPES, R. J. "Papa diz que aborto reflete uma 'cultura do descarte'". Folha de S. Paulo, São Paulo, p. A-10, 14 fev. 2014.

LUNA, N. "O direito à vida no contexto do aborto e da pesquisa com células-tronco embrionárias: disputas de agentes e valores religiosos em um Estado laico". Religião e Sociedade, Rio de Janeiro, vol. 33, no 1, p. 71-97, 2013.

MACHAdo, M. D. C. "Aborto e ativismo religioso nas eleições de 2010". Revista Brasileira de Ciência Política, Brasília, no 7, p. 25-54, jan.-abr. 2012.

"Discursos pentecostais em torno do aborto e da homossexualidade na sociedade brasileira". Cultura y Religión, Santiago de Chile, vol. VII, no 2, p. 48-68, 2013.

MACHADO, M. D. C.; BURITY, J. "A ascensão política dos pentecostais no Brasil na avaliação de líderes religiosos". Dados, Rio de Janeiro, vol. 57, no 3, p. 601-31, jul.-set. 2014.

MANTOVANI, D. "Quem agenda a mídia? Um estudo de agenda-setting a partir da tematização do aborto nas eleições de 2010". Brasília. Tese de Doutorado em Ciência Política. Universidade de Brasília, 2014.

Mello, L. "Familismo (anti)homossexual e regulação da cidadania no Brasil". Estudos Feministas, Florianópolis, vol. 14, no 2, p. 497-508, maio-ago. 2006.

Miguel, L. F. Os partidos brasileiros e o eixo "esquerda-direita". In: KRAuSE, S.; DANTAS, H.; Miguel, L. F. (orgs.). Coligações partidárias na nova democracia brasileira: perfis e tendências. São Paulo: Editora Unesp; Rio de Janeiro: Konrad Adenauer Stiftung, 2010.

dez. 2012 .

"Aborto e democracia". Estudos Feministas, Florianópolis, vol. 20, no 3, p. 657-672, set.-

Miguel, L. F.; FeitosA, F. "O gênero do discurso parlamentar: mulheres e homens na tribuna da Câmara dos Deputados". Dados, Rio de Janeiro, vol. 52, no 1, p. 201-221, mar. 2009.

Ministério dA SAúde. 20 anos de pesquisas sobre aborto no Brasil. Brasília, Ministério da Saúde, 2009.

MotA, F. F.; BiRoli, F. "O gênero na política: a construção do 'feminino' nas eleições de 2010". Cadernos Pagu, no 43, p. 197-231, jul.-dez., 2014.

MotTA, F. M. Não conta pra ninguém: o aborto segundo mulheres de uma comunidade popular urbana. In: AREND, S. M. F., et al. (orgs.). Aborto e contracepção: histórias que ninguém conta. Florianópolis: Editora Insular, 2012.

Oliveira, M. "Médico chama a polícia após atender jovem que fez aborto". Folha de S. Paulo, São Paulo, p. C-5, 21 fev. 2015.

Pinto, C. R. J. Uma história do feminismo no Brasil. São Paulo: Fundação Perseu Abramo, 2003.

RochA, M. I. B. "A discussão política sobre aborto no Brasil: uma síntese". Revista Brasileira de Estudos da População, São Paulo, vol. 23, no 2, p. 369-379, jul.-dez. 2006. 
LUIS FELIPE MIGUEL; FLÁVIA BIROLI; RAYANI MARIANO

RochA, M. I. B. "A questão do aborto no Legislativo brasileiro: uma visão geral dos anos 90 e da década atual". XVI Encontro Nacional de Estudos Populacionais. Caxambu, MG, 29 set.-3 out. 2008.

Rocha, M. I. B; Rostagnol, S.; Gutierrez, M. A. "Aborto y parlamento: un estudio sobre Brasil, Uruguay y Argentina". Revista Brasileira de Estudos Populacionais, São Paulo, vol. 26, no 2, p. 219336, jul.-dez. 2009.

SENRA, R. "ONU defende descriminalização do aborto em meio à epidemia de zika" [online]. BBC Brasil, 5 fev. 2016. Disponível em:

<http://www.bbc.com/portuguese/noticias/2016/02/160205_onu_aborto_zika_rs>. Acesso em: 13 fev. 2016.

VEJA.COM. "Papa condena aborto e eutanásia e adverte: jogar com a vida é pecado" [online]. Veja.com, 15 nov. 2014. Disponível em: <http://veja.abril.com.br/noticia/mundo/papa-condenaeutanasia-e-adverte-brincar-com-a-vida-e-pecado-contra-deus>. Acesso em: 28 fev. 2015.

WARREN, M. A. Moral status: obligations to persons and other living things. Oxford: Oxford University Press, 1997.

Weber, M. A política como vocação. In: Weber, M. Ciência e política: duas vocações. São Paulo: Cultrix, [1919] 1985.

\section{Resumo}

O direito ao aborto no debate legislativo brasileiro: a ofensiva conservadora na Câmara dos Deputados

Este artigo analisa o debate sobre a questão do aborto ocorrido na Câmara dos Deputados brasileira entre 1991 e 2014. Foram analisados 915 discursos, com um mapeamento do sexo e partido dos parlamentares, posições sobre aborto e argumentos mobilizados para sustentá-las ao longo do período analisado. Os dados mostram que há uma crescente ofensiva de parlamentares conservadores no Congresso, em sua maioria religiosos, que têm feito da luta contra o direito ao aborto uma de suas mais importantes bandeiras políticas, colocando na defensiva as posições favoráveis à descriminalização da interrupção voluntária da gravidez ou, ao menos, à ampliação dos casos permitidos pela legislação brasileira. Apesar de sua vinculação às igrejas, os parlamentares que atuam contra o direito ao aborto reduziram, ao longo do tempo, o apelo a argumentos abertamente religiosos, o que demonstra que a questão da laicidade do Estado ganhou algum peso no debate. Entre os defensores da legalização do aborto, os argumentos de saúde pública têm primazia sobre os argumentos ligados à autonomia das mulheres.

Palavras-chave: aborto; democracia; gênero; Câmara dos Deputados; laicidade

\section{Abstract}

The right to abortion in the Brazilian legislative debate: the conservative offensive in the Chamber of Deputies

The article analyzes the debate on the issue of abortion that occurred in the Brazilian Chamber of Deputies between 1991 and 2014. We analyzed 915 speeches, with a mapping of sex and party parliamentarians, positions on abortion, and arguments mobilized to support them over the analysis period. The data show that there is a growing offensive of conservative members of Congress, mainly religious deputies, who have made the fight against abortion rights one of the most important political issues in their agenda, backing positions in favor of the decriminalization of abortion or, at least, the expansion of cases allowed by Brazilian law. Despite its connection to different churches, parliamentarians acting against the right to abortion have reduced, over time, the open appeal to religious arguments, which shows that the value of secularity has gained some 
O DIREITO AO ABORTO NO DEBATE LEGISLATIVO BRASILEIRO: A OFENSIVA CONSERVADORA NA CÂMARA DOS DEPUTADOS

weight in the debate. Among the supporters of the legalization of abortion, public health arguments take precedence over the arguments related to the empowerment of women.

Keywords: abortion; democracy; gender; Chamber of Deputies; laicity

\section{Resumen}

El derecho al aborto en el debate legislativo brasileño: la ofensiva conservadora en la Cámara de Diputados

El artículo analiza el debate sobre el tema del aborto ocurrido en la Cámara de Diputados de Brasil entre 1991 y 2014. Fueron analizados 915 discursos, con un mapeo de sexo y partido de los parlamentarios, posiciones sobre el aborto y argumentos movilizados para apoyarlas durante el período de análisis. Los datos muestran que existe una creciente ofensiva de los miembros conservadores del Congreso, en su mayoría religiosos, que han hecho de la lucha contra el derecho al aborto una de sus banderas políticas más importantes, poniéndose a la defensiva ante posiciones favorables a la despenalización del aborto o, al menos, a la expansión de los casos permitidos por la ley brasileña. A pesar de su conexión con las iglesias, los parlamentarios que actúan contra el derecho al aborto disminuyeron, con el tiempo, la apelación a los argumentos abiertamente religiosos, lo que demuestra que la cuestión de la laicidad del estado ganó algo de peso en el debate. Entre los partidarios de la legalización del aborto, los argumentos de salud pública tienen prioridad sobre los argumentos relacionados con la autonomía de la mujer.

Palabras clave: aborto; democracia; género; Cámara de Diputados; laicidad

\section{Résumé}

Le droit à l'avortement dans le débat législatif brésilien: l'offensive conservatrice à la Chambre des Députés

L'article analyse le débat sur la question de l'avortement qui a eu lieu à la Chambre des Députés du Brésil entre 1991 et 2014. 915 rapports ont été analysés, avec une cartographie du sexe et du parti des parlementaires, des positions sur l'avortement et les arguments mobilisés pour soutenir ces positions au cours de la période d'analyse. Les données indiquent qu'il y a une offensive croissante des membres conservateurs du Congrès, religieux pour la plupart d'entre eux, qui ont fait de la lutte contre le droit à l'avortement un de leurs mots d'ordre politiques les plus importants, mettant sur la défensive les positions favorables à la dépénalisation de l'avortement ou, au moins, à l'expansion des cas permis par la loi brésilienne. En dépit de leur lien avec les églises, les parlementaires agissant contre le droit à l'avortement ont essayé d'éviter, au fil du temps, de faire ouvertement appel aux arguments religieux, ce qui montre que la question de la laïcité de l'Etat a gagné un certain poids dans le débat. Parmi les partisans de la légalisation de l'avortement, les arguments de santé publique ont préséance sur les arguments relatifs à l'autonomisation des femmes.

Mots-clés: avortement; démocratie, genre; Chambre des Députés; laïcité

Artigo submetido à publicação em 6 de maio de 2016. Aprovado para publicação em 7 de março de 2017. 